\title{
Pascal A. Ifri, «Les deux étendards» de Lucien Rebatet. Dossier d'un chef-d'oeuvre maudit
}

\section{Emanuele Kanceff}

\section{(2) OpenEdition}

1 Journals

\section{Edizione digitale}

URL: http://journals.openedition.org/studifrancesi/36688

DOI: $10.4000 /$ studifrancesi.36688

ISSN: 2421-5856

\section{Editore}

Rosenberg \& Sellier

\section{Edizione cartacea}

Data di pubblicazione: 1 juillet 2005

Paginazione: 200

ISSN: 0039-2944

\section{Notizia bibliografica digitale}

Emanuele Kanceff, «Pascal A. Ifri, «Les deux étendards» de Lucien Rebatet. Dossier d"un chef-d'oeuvre maudit», Studi Francesi [Online], 145 (XLIX | I) | 2005, online dal 30 novembre 2015, consultato il 20 avril 2021. URL: http://journals.openedition.org/studifrancesi/36688 ; DOI: https://doi.org/10.4000/ studifrancesi.36688

Questo documento è stato generato automaticamente il 20 avril 2021.

\section{(c) (1)}

Studi Francesi è distribuita con Licenza Creative Commons Attribuzione - Non commerciale - Non opere derivate 4.0 Internazionale. 


\title{
Pascal A. Ifri, «Les deux étendards» de Lucien Rebatet. Dossier d'un chef- d'oeuvre maudit
}

\author{
Emanuele Kanceff
}

\section{NOTIZIA}

PASCAL A. IFRI, «Les deux étendards» de Lucien Rebatet. Dossier d'un chef-d'oeuvre maudit; Lausanne; L'Age d'Hoome, 2001, pp. 207.

1 È certo che Lucien Rebatet ha sofferto dell'ostracismo e del purgatorio letterario che si è attirato con la sua attività politica. Condannato a morte per collaborazionismo e antisemitismo, poi graziato e inviato al bagno penale ove rimase per cinque anni, la sua opera fu ignorata dalla critica e rimane, secondo l'autore, completamente da scoprire. Tuttavia, il romanzo Les deux étendards, pubblicato nel 1952, è stato considerato un capolavoro della letteratura francese del Novecento, anche se l'autore lamenta che esso rimanga un tabù: "A l'aube du XXI ${ }^{\mathrm{e}}$ siècle il est grand temps de briser le mur de silence qui entoure un roman aussi important et de le considérer du seul point littéraire". Il suo libro ricostruisce in una serie di capitoli successivi la figura di Rebatet, la storia del romanzo, la struttura e lo stile del racconto, per allargare poi lo sguardo alla condizione politica e alla società che vi si riflettono, e infine ai temi fondamentali, l'amore, la religione, l'arte e la letteratura.

2 Il libro si conclude con due capitoli in cui, grazie anche a documenti inediti, si mette a punto la presenza biografica nel romanzo e i legami che lo mettono in relazione con i fatti realmente accaduti. 